\title{
BODILY ENCOUNTERS: GLORIA ANZALDÚA'S BORDERLANDS/LA FRONTERA
}

\section{Sandra Regina Goulart Almeida}

\author{
This is her home \\ this thin edge of \\ barbwire. \\ To survive the Borderlands \\ you must live sin fronteras \\ be a crossroads. \\ Gloria Anzaldúa, Borderlands/La Frontera
}

Gloria Anzaldúa's polymorphous text suggests a controversial and contradictory locus of bodily encounters, as the above quotes exemplify: on the one hand, it is, for her, a place which is necessarily defined by the metaphor of the crossroads as a positive and regenerating site that demolishes frontiers and, on the other hand, it is conceived as a painful and treacherous place, a "thin edge of barbwire" (35). This locus of bodily encounters, like Anzaldúa's text itself, is also clearly a gendered space: as she puts it, it is her home, the politicized place she speaks from-the place of the Chicana, the new mestiza.

Gloria Anzaldúa's influential and controversial work, Borderlands/La Frontera (1987), has often been read as a post-modern text that mixes poetry, autobiography, and history; as a theoretical

\begin{tabular}{|l|l|l|l|l|}
\hline Ilha do Desterro & Florianópolis & $n^{\circ} 39$ & p.113-123 & jul./dez. 2000 \\
\hline
\end{tabular}


discourse that explores political, cultural and gender issues, and as an example of Chicana post-colonial writing. While acknowledging the relevance of such analyses, I would like to focus on another, from my viewpoint, equally pertinent and often neglected issue: how the image of the body in Anzaldúa's text, specifically the female body, is portrayed as a contact zone for the constitution of a social space of interaction among the cultures with which she interacts, namely, the Mexican, American-Texan and Native Indian.

The (un)translated body of the text as well, in an explicit reference to the long-standing connection between the female body, the land and writing, functions in this work as a mediator and a border of contact through which the cultural conflicts she describes are played out. In other words, in my reading of Anzaldúa's work, the three elements often referred to- - the land, the body and the text-are equally treated as gendered elements within a framework of displaced identities and cultural intersections. As Anzaldúa states it in Borderlands,

For only through the body, through the pulling of flesh, can the human soul be transformed. And for images, words, stories to have this transformative power, they must arise from the human body-flesh and bone-and from the Earth's body-stone, sky, liquid, soil. This work, these images, piercing tongue or ear lobes with cactus needle, are my offerings, are my Aztecan blood sacrifices. (97)

The above quote stresses the interconnection in her work among the text, the body and the land: "words," "the human body," "the Earth's body" all become united in the image of her "work." This land which is evoked here through the image of the earth, a quintessential feminine element, is elsewhere defined as "the borderland," the locus from which she speaks, the place in which cultures meet and interact with each other. It is described as "a vague and undetermined place created by the emotional residue of an unnatural boundary. It is in a constant state 
of transition" (25). In addition, this borderland is openly viewed in gendered terms: it is the place of the Chicana, the new mestiza:

From this racial, ideological, cultural and biological crosspollinization, an "alien" consciousness is presently in the making-a new mestiza consciousness, una conciencia de mujer. It is a consciousness of the Borderlands. (99)

The "consciousness" to which Anzaldúa refers is gendered and specifically localized: it is simultaneously a woman's consciousness and "a consciousness of the Borderlands." Anzadúa's politics of space partakes of the body politic in social, cultural and geographic terms.

In discussing the role of the body in post-colonial studies, Ashcroft, Griffiths, and Tiffin stress the fact that "the body is a crucial site for inscription" of different kinds. They affirm that

The body, and its importance in post-colonial representation, emphasizes the very special nature of post-colonial discourses. For although the body is a text, that is, a space in which conflicting discourses can be written and read, it is a specially material text, one that demonstrates how subjectivity, however constructed it may in fact be, is "felt" as inescapably material and permanent. (184)

This concept of the body as a text in which cultural conflicts are played out is raised by Anzaldúa as she continuously stresses the bodily exploitation of women in the territorial acquisition of Mexico and Texas by the Spanish and the Americans in a reference to what Ashcroft, Griffiths, and Tiffin call a "special double colonization for women" which "led to a greater concern with the body as a site for gendered readings of post-colonial subjectivity" (184). In Anzaldúa's words:

La mojada, la mujer indocumentada, is doubly threatened in this country. Not only does she have to contend with sexual 
violence, but like all women, she is prey to a sense of physical helplessness. As a refugee, she leaves the familiar and safe homeground to venture into unknown and possibly dangerous terrain. (35)

In Anzaldúa's text, the above citation serves as an introduction to her final statement quoted as the epigraph to my text: "This is her home/this thin edge of barbwire" (35) and problematizes the conflictive site of women's discourse and position in post-colonialism. This statement echoes Gayatri Spivak's concern that "[w]ithin the effaced itinerary of the subaltern subject, the track of sexual difference is doubly effaced" and that "[i]f, in the context of colonial production, the subaltern has no history and cannot speak, the subaltern as female is even more deeply in shadow" (82-83).

Seen in juxtaposition with Anzaldúa's more positive imagery of the "borderlands," the reference to this site that is women's home, "her home", her location, her locus of enunciation, Chicana borderland, as a "thin edge of barbwire" may seem rather problematic and antithetical. However, I contend that this apparently contradictory impulse mirrors the very structure of Anzaldúa's text and the central argument she wants to raise. In fact, this site that she chooses to call "borderlands" is defined as a "place of contradictions," transgressions, shock. It is a "third country," a mediator, a third term, a liminal space of inbetweenness, a hybrid place, that is, a contradictory and ambivalent place from which a problematized notion of cultural identity emerges, without any trace of a fundamental or essential purity or originality. This metaphor of the borderlands is visualized in Homi Bhabha's empowering notion of hybridity and the Third Space:

the theoretical recognition of the split-space of enunciation may open the way to conceptualizing an intemational culture, based not on the exoticism of multiculturalism or the diversity of cultures, but on the inscription and articulation of culture's hybridity. To that end we should remember that it 
is the 'inter' - the cutting edge of translation and negotiation, the in-between space-that carries the burden of the meaning of culture. It makes it possible to begin envisaging national, anti-nationalist histories of the "people." And by exploring this Third Space, we may elude the politics of polarity and emerge as the other of our selves. (38-39)

In a way it can be said that Anzaldúa's concept of the "borderlands" as a site in which standardized dichotomies are problematized and contradictions are unveiled and valorized puts in practical and performative terms years earlier the concepts developed by Bhabha's notion of hybridity.

It is interesting to notice how Anzaldúa also works out this theory of the borderlands, of hybridization, in terms of female imagery, figures, and roles, seen in sexual and bodily terms in their culture. These female cultural figures evoke Julia Kristeva's notion of women as boundarysubjects. In Kristeva's words, "[w]omen have the luck and responsibility of being boundary-subjects: body and thought, biology and language, personal identity and dissemination during childhood, origin and judgment, nation and world" (35).

One of the most striking examples of this image of women as boundary-subjects is Anzaldúa's re-reading of three female traditional mythic figures of Mexican culture, which she calls "cultural figures" (241) or, as Alarcón puts it, "oppositional mediating figures" ("Traddutora" 112) - la Virgen de Guadalupe and Malintzín, la Chingada. However, Anzaldúa chooses to provide a different reading of their historical and cultural influences, a counter discursive practice as a strategy of resistance and empowerment and it is upon this subversive re-reading or deconstruction that her text is fabricated.

Anzaldúa accuses the male-dominated Aztec-Mexican culture and, later on, the Catholic religion brought by the Spaniards of forcing a split of the female deities into dichotomous images: good and evil women figures, or as she puts it, "the virgen/puta (whore) dichotomy" (53). Her argument is that: 
After the Conquest, the Spaniards and their Church continued to split Tonantsi/Guadalupe. They desexed Guadalupe, taking Coatlalopeuh, the serpent/sexuality, out of her. They completed the split begun by the Nahuas by making la Virgen de Guadalupe/Virgen Maria into the Beauties and the Beasts. (49-50)

Rather than endorsing the stereotypical and Manichaen portrayal of these images, Anzaldúa's narrative enacts an invigorating re-reading of their symbology, a new version of women's trope, one that visualizes the female body and women's sexuality as empowering and as inherent to her borderland metaphor. She tells us that la Virgen de Guadalupe's Indian name is Coaltlalopeuh, who is descended from Coatlicue, the Serpent goddess. Thus, in Anzaldúa's reading of the origin of the myth, Guadalupe embodies concomitantly the two dichotomous qualities with which women have traditionally been forced to identify: the sexuality associated with the symbol of the serpent in opposition to the idealization evoked by the image of the virgin mother (49). This image of Guadalupe becomes, then, simultaneously and transgressively a synthesis and an opposition.

Likewise, the image of Malintzín as la Chingada, for Anzaldúa, is a male construct devised to make women believe that the Indian woman in them is the betrayer. She affirms: "We, indias y mestizas, police the Indian in us, brutalize and condemn her. Male culture has done a good job on us" (44). In Anzaldúa's reading, however, Malintzín becomes not a traitor of her country but a transgressor of roles, acquiring highly positive connotations for daring to reject the role of the good mother and for acknowledging her sexual power as a seducer, and her strength as a translator, a woman who speaks. Therefore, like la Virgin de Guadalupe, Malintzín is placed in-between roles and stereotypes.

By choosing to rescue these traditional native images from destructive appropriation from male western culture, Anzaldúa provides not only a divergent reading of cultural constructs, but also formulates a theoretical model that accounts for displaced identities 
and cultural intersections in this mediating space that she calls the borderlands. For her, Guadalupe is a mediator, a border figure in that she becomes a "synthesis of the old world and the new," and a contact zone "between the Spanish and the Indian cultures" (52). In fact, Anzaldúa's arguments attempt to dislocate dichotomies by introducing a third element in this traditionally dualistic pattern: la llorona, a combination of the other two, a hybrid mythic image. These three mother figures of the Chicano people, which according to her historical account, have been subverted to fit the virgen/puta dichotomy, become actually, in her reading, powerful mediator female figures. She identifies the three women as: "Guadalupe, the virgin mother who has not abandoned us, la Chingada (Malinche), the raped mother whom we have abandoned, and la Llorona, the mother who seeks her lost children and is a combination of the other two" (52).

Anzaldúa's embodiment of the borderlands and of this hybrid state, however, is shifted to the image of Coatlicue, Lady of the Serpent Skirt, who "contained and balanced the dualities of male and female, light and dark, life and death," who is "a protean being" and a symbol of the contradictory and the representative of a "third perspective" (5469). She calls this female image of the borderlands "The Coatlicue State," and conceives it in terms of the female body, basing her argument in the historical fact that womanhood was often associated in ancient times with the Serpent's mouth guarded by teeth, an image clearly evocative of the terrifying myth of the vagina dentata. As such it is related to the contradictory and complementary feminine power of life and death, creativity and destruction, light and darkness-a symbol of a synthesis of duality, the personification of a third term. As Anzaldúa puts it:

Coatlicue depicts the contradictory. In her figure, all the symbols important to the religion and philosophy of the Aztecs are integrated. Like Medusa, the Gorgon, she is a symbol of the fusion of opposites: the eagle and the serpent, 
heaven and the underworld, life and death, mobility and immobility, beauty and horror. (69)

For Anzaldúa, Coatlicue represents the power and inner self of the Chicana and as such she is emblematic of a synthesis of all the other deities: "Coatlicue-Cihuacoatl-Tlazolteotl-TonantzinCoatlalopeuh-Guadalupe" (72). This image of conciliation provided by Anzaldúa in some ways evokes a painting by Yolanda López, a Chicana artist who produces several feminist revisions of the Guadalupe imagery in "The Guadalupe Series" (1978). These, like Anzaldúa's text, question stereotypical notions of gender and cultural identities and supply alternative and powerful models of mythic women figures. In Portrait of the Artist as the Virgen de Guadalupe (1978), López depicts herself in a self-portrait as the Guadalupe figure. In this painting, the artist, bearing a triumphant smile on her face, runs forward holding a snake in one hand and a "super-heroine-like cape in the other" (Pérez 29-34). In her struggle forward, the artist steps on an angel with dark features, representative of Chicana people, whose wings have the color of the American flag. Such a defiant and powerful portrayal provides an interesting intertext with Anzaldúa's work: in both pieces, Guadalupe is divested of her traditional image and vested with a supernatural quality associated with that of the heroic Serpent woman. A similar image is evoked in a poem from Borderlands/La Frontera in which the poetic voice predicts the moment when, like López's woman, Chicanas will be able to let the Serpent woman inside themselves emerge:

Yes, in a few years or centuries la Raza will rise up, tongue intact carrying the best of all the cultures. That sleeping serpent, rebellion-(r)evolution, will spring up. Like old skin will fall the slave ways of obedience, acceptance, silence. 
Like serpent lightning we'll move, little woman.

You'll see. (225)

It is also relevant to observe that in both pieces the artists use themselves as the focus and as the producer of this transgressive and defiant discourse. In the same way that López portrays herself in the painting as a parodic version of the Guadalupe/The Serpent myth, Anzaldúa inscribes her authorial voice in her text by identifying herself with Coatlicueand by visualizing her writing as a powerful weapon to transgress culturally biased representations. In fact, her very writing is described as a facet of Coatlicue, "a rebellious, willful entity a precocious girl-child" (88). Later on, she adds, referring to her writing as a powerful weapon: "I will no longer be made to feel ashamed of existing. I will have my serpent's tongue-my woman's voice, my sexual voice, my poet's voice. I will overcome the tradition of silence" (81). To overcome the tradition of silence is, according to Norma Alarcón, one of the roles of the Chicana feminist. As she put it,

Given the extensive ideological sedimentation of the (silent) Good Woman and the (speech producing) Bad Woman that enabled the formations of the cultural nationalistic "communal modes of power," Chicana feminists have an enormous mandate to make "sense" of it all, as Anzaldúa desires. ("Chicana Feminism" 70-71)

Ironically, for Alarcón, in a binary, Manichaen system of thought, Guadalupe stands for silence and maternal self-sacrifice as positive attributes while Malintzín evokes the "woman who speaks as sexual being and independently of her maternal role" ("Traddutora" 113). We have seen that Anzaldúa refuses such stereotypical reading and, on the contrary, tries to subvert it. Writing for Anzaldúa is the means to overcome the tradition of silence she often talks about and this belief may justify her defense of Malintzín, for her, the emblematic figure of the native woman who actually speaks her mind. Hers is a writing that 
comes from her body, a body of the frontiers, of the boderlands, because she believes: "Being a writer feels very much like being a Chicana, or being queer.... Living in a state of psychic unrest, in a Borderland, is what makes poets write and artists create.... It (the creative act) is constantly remaking and giving birth to itself through my body" (95). Unlike Malintzín's historical role, however, Anzaldúa's text, which comes from the borderlands and is written through her body, is "untranslatable" precisely because hers is a text and a "language of the boderlands," and as such they are multiple and various and refuse to be transformed into a whole or unitary piece.

In conclusion, Anzaldúa's Borderlands/La Frontera problematizes her locus of enunciation by using the rhetoric of borders and hybridities in a world inhabited by multiple cultures. Her Coatlicue State, the embodiment of the contradictions and ambiguities evoked by the metaphor of the borderlands, is visualized as a gendered state of consciousness, as the convergence of a multiplied text/body/land. In a reference to Bhabha, it is a third space evocative of possibilities, "a multiply placed/linked subject" (Grewal 235). As Anzaldúa puts it: "It is this learning to live with la Coatlicue that transforms living in the Borderlands from a nightmare into a luminous experience. It is always a path/state to something else" (95). In this context, her very text becomes, then, "a path/state to something else" as it questions fixed and biased cultural notions and opens space for a third possibility, one that points to "a new mestiza consciousness" constantly "in the making" (99). It is, what I would call, a sliding category of space, one that is not fixed or preestablished: neither subject nor other, but an agent in a constantly sliding position. This locus of enunciation is undoubtedly characterized by a concept that "slides," that "shifts," that is, a mode of articulation in a constant dialogue with other forms of expression and power relations, a product of a paradoxical and ambivalent condition within a given cultural context. It is a place marked socially and geographically, pluralized because of social, cultural, economical, and political differences, but that remains "movable," hybrid and mutable through a multiplicity of codes and positionings. 


\section{Bibliography}

Alarcón, Norma. "Chicana Feminism: In the Tracks of the Native Woman". Between Woman and Nation: Nationalisms, Transnational Feminisms, and The State. Eds. Caren Kaplan, Norma Alarcón, and Minoo Moallem. Durham and London: Duke University Press, 1999. 63-71

"Traddutora, Traditora: a Paradigmatic Figure of Chicana Feminism." Scattered Hegemonies: Postmodernity and Transnational Feminist Practices. Eds. Inderpal Grewal and Caren Kaplan. Minneapolis: University of Minnesota Press, 1994. 110-133.

Anzaldúa, Gloria. Borderlands/La Frontera. San Francisco: Aunt Lute Books, 1987.

Ashcroft, Bill; Gareth Griffiths, and Helen Tiffin. "Post-Colonial Body". Key Concepts in Post-Colonial Studies. London and New York: Routledge, 1998. 183-86.

Bhabha, Homi. The Location of Culture. London and New York: Routledge, 1994.

Grewal, Inderpal. "Autobiographic Subjects and Diasporic Location: Meatless Days and Borderlands". Scattered Hegemonies: Postmodernity and Transnational Feminist Practices. Eds. Inderpal Grewal and Caren Kaplan. Minneapolis: University of Minnesota Press, 1994. 231-54.

Kristeva, Julia. Nations Without Nationalism. Trans. Leon S. Roudiez. New York: Columbia University Press, 1993.

Pérez, Laura Elisa. "El Desorden, Nationalism, and Chicana/o Aesthetics." Between Woman and Nation: Nationalisms, Transnational Feminisms, and The State. Eds. Caren Kaplan, Norma Alarcón, and Minoo Moallem. Durham and L o n d on : Duke University Press, 1999. 19-46.

Spivak, Gayatri Chakravorty. "Can the Subaltern Speak". Colonial Discourse and Post-Colonial Theory. Eds. Patrick Williams and Laura Chrisman. New York: Harvester-Wheatsheaf, 1994. 66-111. 